\title{
Why encouraging more people to become entrepreneurs is bad public policy
}

\author{
Scott Shane
}

Accepted: 1 March 2009/Published online: 9 June 2009

(C) Research Institute of Industrial Economics 2009

\begin{abstract}
Policy makers often think that creating more start-up companies will transform depressed economic regions, generate innovation, and create jobs. This belief is flawed because the typical start-up is not innovative, creates few jobs, and generates little wealth. Getting economic growth and jobs creation from entrepreneurs is not a numbers game. It is about encouraging the formation of high quality, high growth companies. Policy makers should stop subsidizing the formation of the typical start-up and focus on the subset of businesses with growth potential. While government officials will not be able to "pick winners," they can identify start-ups with a low probability of generating jobs and enhancing economic growth. By
\end{abstract}

Scott A. Shane is the 2009 Winner of the Global Award for Entrepreneurship Research. This essay is the Prize Lecture given upon receipt of the Award on 12 May 2009 in Stockholm, Sweden. More information about the Prize and previous Winners is available at www.e-award.org. This lecture draws on Scott Shane's new book: Illusions of Entrepreneurship: The Costly Myths that Entrepreneurs, Investors and Policy Makers Live By (Yale University Press, 2008).

S. Shane $(\square)$

Case Western Reserve University, Cleveland, OH, USA

e-mail: scott.shane@case.edu eliminating incentives to create these low probability companies, policy makers can improve the average performance of new businesses.

Keywords Economic growth · Entrepreneurship · Entrepreneurship Award Winner · Job creation . New firm formation

JEL Classifications J24 $\cdot$ L26 $\cdot$ M13

\section{Introduction}

Policy makers believe a dangerous myth. They think that start-up companies are a magic bullet that will transform depressed economic regions, generate innovation, create jobs, and conduct all sorts of other economic wizardry. Leading economist Edward Lazear (2005, p. 649) has even claimed that "the entrepreneur is the single most important player in a modern economy." So they provide people with transfer payments, loans, subsidies, regulatory exemptions, and tax benefits if they start businesses. Any businesses.

Take, for example, the remarks of former U.S. President George W. Bush who said, in a speech to the Small Business Week Conference (Bush 2006): "Small businesses are vital for our workers.... That's why it makes sense to have the small business at the cornerstone of a pro-growth economic policy.... The 
Small Business Administration is working hard to make it easier for people to start up companies. We understand that sometimes people have got a good idea, but they're not sure how to get something started.... And so we've doubled the number of small business loans out of the SBA since I came to office."

Or take a speech by British Prime Minister Gordon Brown to the International Monetary Fund (Brown 1998): "Britain cannot be properly equipped while we have productivity levels 40 per cent below America, and 20 per cent below France and Germany, so over the next year, in partnership with industry, we intend to examine and begin the task of dismantling every barrier to productivity, prosperity and employment creation. That will require policies to promote entrepreneurship and small business development."

This is bad public policy. Encouraging more and more people to start businesses won't enhance economic growth or create a lot of jobs because start-ups, in general, aren't the source of our economic vitality or job creation.

You might be startled by this position, going, as it does, against the grain of most popular arguments. It might even seem illogical to you. After all, companies like SAP in computer software, Google in Internet search, and Genentech in biotechnology, are all examples of wildly successful start-ups. And the list need not stop there. EasyJet and Wal-Mart were also start-up companies not too long ago. So, surely, these companies must have contributed to economic growth?

\section{The economic growth myth}

Yes, of course, they have. But, those companies are not typical start-ups. In the United States, the typical startup is a company capitalized with about $\$ 25,000$ of the founder's savings that operates in retail or personal services (Hurst and Lusardi 2004). Odds are pretty good that it is a home-based business (Pratt 1999), and the founder aspires to generate around $\$ 100,000$ in revenue in five years (Haynes 2001). The vast majority of people founding new businesses aren't entrepreneurs in the sense of people building companies that grow, generating both jobs and wealth. Rather, they are founding wage-substitution businesses that have more in common with self-employment than with the creation of high growth companies. ${ }^{1}$

This is not a U.S.-only phenomenon. Across the 34 countries in the Global Entrepreneurship Monitor dataset, the typical start-up founded between 1998 and 2003 required $\$ 11,400$ in capital. So even at the time that SAP, or Google or EasyJet were founded, they weren't anything like the typical new business.

To get more economic growth by having more start-ups, new companies would need to be more productive than existing companies. But they are not. Haltiwanger, Lane, and Speltzer (1999), combined data from the U.S. Census and other sources to look at the relationship between firm productivity and firm age. The results showed that firm productivity increases with firm age. This means that, at least in the United States, the average new firm makes worse use of resources than the average existing firm, which is not what you would expect if economic growth benefits more from the creation of new firms than from the expansion of existing ones. And you shouldn't think that the typical start-up makes up for its poor productivity when it gets older because typical U.S. start-up is dead in five years.

This pattern makes sense because there should not be positive correlation between economic growth and the rate at which typical start-ups are formed over the long term. As countries become wealthier, the rate at which they create start-ups goes down. Societal wealth leads average wages go up, which encourages business owners to use machines to replace work that

\footnotetext{
${ }^{1}$ Some observers have sought to distinguish between these types of entrepreneurs by calling them "opportunity" and "necessity" entrepreneurs or by distinguishing between "selfemployment" and "entrepreneurship" (Henrekson 2007). While I am sympathetic to the authors' goal of getting academics and policy makers to break out of a focus on average and typical entrepreneurs, which underlies their labeling, I don't believe that these distinctions work. "Opportunity" and "necessity" entrepreneurship refer to the trigger for starting a business. People can build high-growth, jobcreating, wealth-generating companies even if their motivation for starting a business was necessity. Moreover, the majority of "opportunity" entrepreneurs are not interested in growing their businesses, and fewer still manage to do so. The distinction between "self-employment" and "entrepreneurship" fails because many people who start businesses that generate virtually no jobs or wealth have founded businesses that employ others, making them more than just self-employed. However, they have no intention or ability to build high-growth companies.
} 
used to be done by hand. Capital (the machinery) is subject to greater economies of scale - the reduction in the cost of production that comes from generating things in higher volume - than labor. As a result, the increased use of capital leads companies to grow in size and hire people who would otherwise have gone into business for themselves (Niels Noorderhaven et al. 2004).

Moreover, when countries get wealthier and real wages rise, the opportunity cost of running your own business goes up because the amount of money that you could have earned working for someone else increases. This increased opportunity cost leads more people to go to work for others than when real wages were lower (Caree et al. 2002).

Finally, as countries get richer, they change where economic value is created; first from agriculture to manufacturing, and then from manufacturing to services. Economist David Blau explained that as the source of economic value shifts toward activities where self-employment is less common, like manufacturing, from activities where self-employment is more common, like agriculture, the proportion of people running their own businesses drops (Blau 1987). In the United States, the decline in the importance of agriculture to the overall economy led to a decline in the unincorporated self-employment rates from 12 percent in 1948 to 7.5 percent in 2003 (Hippel 2004). Similar patterns can be seen in most of the other OECD countries.

So if you want to find countries where there are a lot of entrepreneurs, go to Africa or South America. As Fig. 1 shows, the correlation across countries between percent of a country's gross domestic product that comes from agriculture and the country's level entrepreneurial activity is 0.66 , a pretty strong relationship.

Rich countries are richer than poor countries because they had more economic growth in the past. So, if we measure new business creation and economic growth over a long enough horizon to see real differences in economic growth between countries, the countries that have had consistently faster economic growth (the rich ones), actually have declining rates of new firm formation.

In fact, if we look at the correlations between rates of new firm formation and economic growth over the medium-to-long term, we see that firm formation declines as economic growth increases. For instance, the correlation between real GNP growth rates and

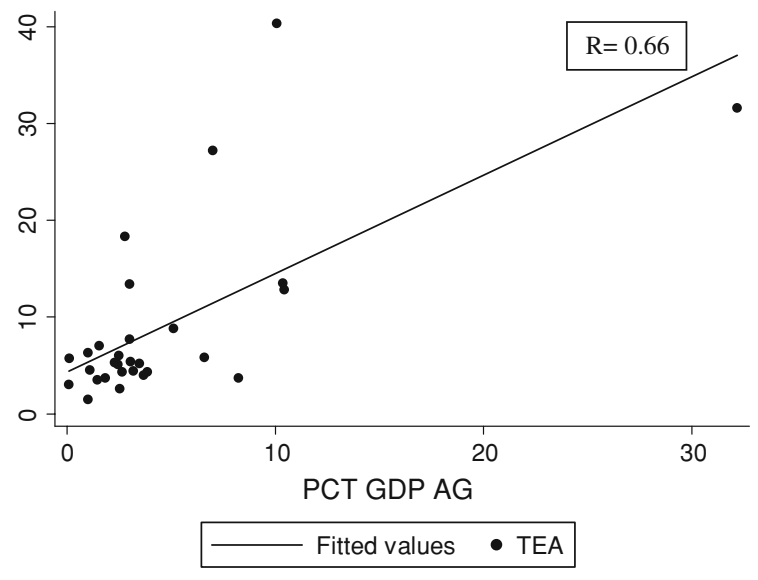

Fig. 1 The correlation across countries between the percentage of value-added in agriculture and total entrepreneurial activity in 2004. Source: Calculated from data from the Global Entrepreneurship Monitor and the World Development Report

the rate of self-employment in France, West Germany, and Italy between 1953 and 1987, and in Sweden between 1962 and 1987 is negative (Bogenhold and Staber 1991), as is the correlation in the 19 OECD countries for which data are available from 1975 to 1996 (Blanchflower 2000).

We also have ample evidence that when governments intervene to encourage the creation of new businesses, they stimulate more people to start new companies disproportionately in competitive industries with lower barriers to entry and high rates of failure. That's because the typical entrepreneur is very bad at picking industries and choosing the ones that are easiest to enter, not the ones that are best for start-up (Johnson 2004). Rather than picking industries in which new companies are most successful, most entrepreneurs pick industries in which most start-ups fail. In the United States, the correlation across industries between start-up rates and failure rates is a whopping 0.77 . So by providing incentives for people to start businesses in general, we provide incentives for people to start the typical business, which is gone in a few years.

And who is most likely to respond to those incentives and start businesses? Not the best entrepreneurs. We know that unemployed people are more likely to start businesses than people who have jobs. Why? Because they have less to lose by becoming entrepreneurs; something economists call a lower opportunity cost on their time. After all, it's less costly to you to start a company if your alternative is 
watching daytime T.V., than if it is taking home a paycheck from a job.

The problem is that people who are unemployed also tend to perform worse when they start companies than people who quit their jobs to start businesses, probably because their hurdle for what kind of business passes the hurdle to pursue is much lower. So policies designed to increase the total number of new businesses disproportionately attract the worst entrepreneurs.

\section{The job creation myth}

Okay, new firm formation might not enhance economic growth, but, as everyone knows, new firms create more jobs than existing firms. As, John Case (1995), commentator for Inc Magazine explained, "Most of the 20 million new jobs created during the past 15 years came not from established giants, the companies that had led America's growth up till then. The jobs came from companies that were smaller, newer - or both. They came from that 'independent entrepreneurial sector'."

It turns out that Mr Case, and the others who make the same argument, are wrong. Very few people work in new firms. According to Acs and Armington (2004), companies with at least one employee that are less than two years old, account for only 1 percent of all employment in the United States. By contrast, companies with at least one employee that are more than ten years old, account for 60 percent of all employment in the United States.

But companies add and shed jobs every year. So companies that didn't exist last year can start and hire employees, while firms in existence last year can add jobs or lose them. So how many jobs do new businesses create? Data provided on its website by the U.S. Bureau of Labor Statistics shows that $31,472,000$ jobs were created in the United States in 2004 (Bureau of Labor Statistics 2008). That year, 580,900 new firms with at least one employee were started, each of which had an average of 3.8 employees. Thus, in 2004, new firms created 2,207,420 jobs in the United States, or 7 percent of the total number of jobs created in that year.

This pattern is not limited to the United States. Davidsson and Delmar (2000) found that only 1.7 percent of the ten year job growth of surviving firms in Sweden was generated by firms two years old and younger in the observation year. By contrast, 74.5 percent of the job growth was generated by companies ten or more years old.

Measuring net job creation - new jobs created minus old jobs lost - is a whole lot harder than measuring gross job creation. So we have fewer estimates of it. But estimates of net job creation by new firms are remarkably similar to the estimates of gross job creation. Davis and Haltiwanger (1992) found that, in U.S. manufacturing, one year old firms created 6.4 percent of the net new jobs, an estimate that is consistent across industries, regions, firm size, and type of firm ownership.

New firms account for a minority of gross and net job creation. In fact, to get to 50 percent of net new jobs that are created by new firms, you have to consider all firms that are nine years old or less to be "new". Anyone with children knows that nine-year-olds are not "new" and pretty different from new born babies.

Okay, so every year a cohort of new firms is founded that generates about 7 percent of the new jobs created in that year. But how many jobs does that cohort of firms account for in its second year? And what about in its third year? And in all years after that? On average, the answer is none. For instance, Knaup (2005) found that the cohort of new employer firms founded in the United States in 1998 employed 798,066 people in its first year, but employed only 670,111 people in 2002 (see Table 1). In other words, the number of jobs lost by new firms that close down in their second year, third year, fourth year, and so on, exceeds the number of jobs added by the expansion of the new firms that survive (Kirchhoff 1994; Persson 2004; Wagner 1994). Far from being job creators, as a whole, new firms have net job destruction after their first year.

Again, this is not just a U.S. phenomenon. Studies conducted in Sweden and Germany also show that each cohort of new firms employs more people in its first year than it employs in any year after that (Kirchhoff 1994; Persson 2004; Wagner 1994).

It also takes a lot of entrepreneurs to create lasting jobs. To get one business employing at least one person in ten years, we need 43 entrepreneurs to begin the process of starting a company. And how many jobs will that start-up have, on average, ten years after it was founded? For the United States, the answer is 9 . In short, 43 people have to try to start 
Table 1 Employment of the 1998 cohort of new employer firms in the United States

\begin{tabular}{|c|c|c|c|c|c|}
\hline Sector & 1998 & 1999 & 2000 & 2001 & 2002 \\
\hline Overall & 798,066 & 792,131 & 781,506 & 721,103 & 670,111 \\
\hline Natural resources and mining & 21,809 & 19,781 & 19,945 & 17,636 & 16,789 \\
\hline Construction & 98,750 & 94,468 & 84,550 & 75,256 & 69,426 \\
\hline Manufacturing & 45,670 & 51,271 & 52,055 & 50,073 & 45,732 \\
\hline Trade, transportation and utilities & 139,125 & 140,472 & 137,448 & 127,135 & 118,266 \\
\hline Information & 17,794 & 22,064 & 25,085 & 22,131 & 18,241 \\
\hline Financial activities & 46,098 & 47,745 & 46,314 & 43,855 & 41,665 \\
\hline Professional and business services & 137,908 & 154,160 & 170,016 & 158,281 & 147,618 \\
\hline Education and health services & 57,068 & 64,594 & 67,017 & 65,534 & 64,881 \\
\hline Leisure and hospitality & 156,668 & 139,041 & 126,323 & 114,154 & 105,941 \\
\hline Other services & 69,736 & 55,664 & 49,639 & 45,027 & 39,932 \\
\hline
\end{tabular}

Source: Adapted from Knaup (2005, pp. 50-56)

companies so that we can have 9 jobs a decade from now. That's not the spectacular yield that you might think we'd get if you read the press reports about the job creation of start-ups.

So far we have talked about the jobs that start-ups create as if they are the same as the jobs in existing companies. But they are not. They are worse. Wagner (1997) showed that jobs in new firms pay less, offer worse fringe benefits, and provide less job security than jobs in existing firms.

The data show that jobs in new firms are more likely to be part-time than jobs in existing firms. Moreover, jobs in the average new firm do not pay as well as jobs in the average existing business. Reynolds and White (1997) found that, in the United States, the average new job paid 72 percent of the average wage in the state in the firm's first year and that the wages in those firms were still below the state average when they were four years old.

Jobs in new firms also offer fewer benefits than jobs in existing firms. According to an analysis of the Federal Reserve Board's survey of small business finances, U.S. businesses become more likely to offer a pension plan or health insurance coverage to their employees as they get older (Bernstein 2002).

The size of the difference in the tendency of new and existing firms to offer health insurance is substantial. In the United States, men who work for others are three times as likely, and women who work for others are six times as likely, to have health insurance, as those who work for themselves (Wellington 2001). Moreover, preliminary data from Kauffman Firm Survey show that, in 2004, only 23.2 percent of new U.S. firms offered health insurance to their full-time employees.

Jobs in new firms are also less likely to be around in the future than jobs in existing businesses, largely because the survival rate of new firms is so low. The probability that jobs created by new firms in the services sector in the United States would still be around four years later was 10 to 13 percent lower than the probability for all (new and established) businesses in that sector. In manufacturing, the numbers were worse. The probability that a job created in a new firm would still be around four years later was 20 percent below that of jobs created in all firms (Armington and Acs 2003).

\section{The policy solution}

Clearly, creating typical start-ups isn't the way to enhance economic growth and create jobs. So what is? It is pretty straightforward. Stop subsidizing the formation of the typical start-up and focus on the subset of businesses with growth potential. Getting economic growth and jobs creation from entrepreneurs is not a numbers game. It is about encouraging high quality, high growth companies to be founded.

The evidence on high-growth start-ups is consistent. A tiny sliver of companies accounts for the vast majority of the contribution to job creation and economic growth that comes from entrepreneurial activity. These gazelles more than make up for the lack of job and wealth creation of the typical start-up 
(Henrekson and Johansson 2009). Moreover, because many gazelles are fairly old and large at the time that they become major wealth and job creators, the story is even more extreme for start-ups. A very small number of new companies account for a disproportionately large amount of wealth and job creation.

These companies are very difficult to pick out ahead of time, making it hard to categorize them. However, one dimension on which they can be identified is their source of financing. According to data from the National Venture Capital Association, since 1970, U.S. venture capitalists have funded an average of 820 new companies per year. These 820 start-ups - out of the more than two million companies started in the United States every year have enormous economic impact. A report posted on the Venture Impact website explains that, in 2003, companies that were backed by venture capitalists employed 10 million people, or 9.4 percent of the private sector labor force in the United States, and generated $\$ 1.8$ trillion in sales, or 9.6 percent of business sales in this country (Venture Impact 2004). Moreover, in 2000, the 2,180 publicly companies that received venture-capital backing between 1972 and 2000 comprised 20 percent of all public companies in the United States, 11 percent of their sales, 13 percent of their profits, 6 percent of their employees, and onethird of their market value, a figure in excess of $\$ 2.7$ trillion dollars (Gompers and Lerner 2001).

In short, the question is not whether having a large number of typical start-ups is better than having a small number of high-growth start-ups. The latter is clearly better.

This pattern has important implications for policy makers. Instead of just believing naively that all entrepreneurship is good and developing policies to increase the number of average or typical entrepreneurs, policy makers need to recognize that only a select few entrepreneurs will create the businesses that will take people out of poverty, encourage innovation, create jobs, reduce unemployment, make markets more competitive, and enhance economic growth. Therefore, as unfair as it might sound, policy makers need to "stop spreading the peanut butter so thin." 2

\footnotetext{
$\overline{2}$ For European readers unaccustomed to the peanut butter and jelly sandwich, substitute the words "butter" or "jam" for "peanut butter" here.
}

They need to recognize that all entrepreneurs are not created equal. They need to think like venture capitalists and concentrate time and money on extraordinary entrepreneurs, and worry less about the typical ones. That means identifying the select few new businesses, out of the multitude of start-ups created each year, which are more productive than existing companies, and investing in them.

How? First, we need to reduce the incentives that we give marginal entrepreneurs to start businesses by reducing the transfer payments, loans, subsidies, regulatory exemptions, and tax benefits that encourage more and more people to start businesses. Because the average existing new firm is more productive than the average new firm, we would be better off economically if we got rid of policies that encouraged a lot of people to start businesses instead of taking jobs working for others.

Take, for example, the home office tax deduction in the United States. Half of all new businesses are home-based businesses. So people who start businesses that they operate out of their homes can deduct the costs of using part of their homes for their businesses - a deduction not available to them if they work for someone else - which gives people an incentive to start companies that do little to enhance economic growth or to create new jobs.

Alternatively, consider the active labor market policy in Germany, which seeks to turn unemployed people into entrepreneurs. The German government spends around $\$ 12$ billion Euros per year on this program (Baumgartner and Caliendo 2007). This figure is not far off the $\$ 20$ billion or so per year that U.S. venture capital firms invest in start-up companies. But what does the German government get for its investment? Certainly not companies that go public, grow their sales, and create jobs the way that the companies backed by U.S. venture capitalists do. Instead, what they get is marginal businesses that create few jobs and have high failure rates.

Or consider the situation in France. According to one web site (Justlanded.com 2008): "There are over 250 different grants and subsidies ... available to individuals for starting up a personal enterprise or small business in France, particularly in rural areas. These include EU subsidies, central government grants, regional development grants, redeployment grants, and grants from departments and local communities." What does the French government get for 
these 250 different programs, other than employment for a large number of government bureaucrats? It is difficult to know for sure since no study has been done on the companies backed by all of these grants and subsidies, but the lack of easy-to-identify, high growth, high employment-generating, post-IPO companies that have been backed by these programs, suggests that the returns have not been spectacular.

So what should policy makers be doing instead? They should reallocate resources to programs that support high growth companies. For instance, in the United States, policy makers could shift money into the Small Business Innovation Research Program, which requires federal government agencies to set aside a portion of their budgets to support commercially viable $R \& D$ projects at small companies. The recipients of these funds are much more likely than the typical start-up to contribute to economic growth and to create jobs.

In France, policy makers on the right track with the 50 percent $R \& D$ tax credit. Even when it is reduced to 30 percent in the third and subsequent years (Investin France.org 2008), this R\&D tax credit exceeds the onagain-off-again 20 percent tax credit for U.S.-based research and development expenditures. $R \& D$ tax credits offer an incentive for entrepreneurs to conduct research and development that they otherwise would not undertake. Those new companies that conduct R\&D, and which would benefit from this credit, are more likely than the typical start-up to contribute to economic growth and job creation.

These are merely two few examples of policies we could change. The general principle is to shift resources from programs that support generic entrepreneurship efforts to those that support high potential businesses.

Some commentators argue that we cannot just focus on the small number of highly successful startups because we do not know which start-ups will become high growth businesses and which won't. To these commentators, the answer is to throw mud against the wall and see what sticks.

This view may be politically appealing, but it is naïve. It assumes that we cannot identify the things that make new businesses more likely to survive, generate profits, increase sales, and hire people. Unless the beliefs of venture capitalists and sophisticated business angels are completely wrong, we know what criteria to focus on. Between the human capital of the founder and his motivations, the industries in which companies are founded, their business ideas and strategies, and their legal forms and capital structure, among other things, we have a lot of information on which to choose likely winners from likely losers.

In fact, most people know how to select the companies to bet on. Take, for example, following two businesses:

- A personal cleaning business that is started by an unemployed high school drop out, that is pursuing the customers of another personal cleaning business, and is capitalized with $\$ 10,000$ of the founder's savings.

- An Internet company that is started by a former SAP employee with fifteen years of experience in the software industry, an MBA and a master's degree in computer science, that is pursuing the next generation of Internet search, and is capitalized with $\$ 250,000$ in money from the founder and a group of business angels.

Which one would you put your resources behind? It's obvious that the second business' chances to contribute to economic growth and create jobs are far better than the first's and that, on average, we would be better off putting our resources into businesses like it.

In fact, policy makers know how to make this choice too. Although skeptics often ask for examples of public programs in which policy makers choose companies to back and end up picking winners, thinking that there are no examples, it turns out that there are. Take the Small Business Investment Corporation program in the United States as an example. This program has used taxpayer dollars to support the following companies, among others: America OnLine; Amgen, Inc.; Apple Computer; Callaway Golf Company; Compaq, Inc.; Costco; Cray Research; DoubleClick.com; Duracraft Corporation; Evergreen Solar, Inc; Extreme Networks, Inc; Federal Express; Fusion Systems Corp; Gymboree Corporation; HealthSouth Rehabilitation; Intel Corp.; Jenny Craig, Inc.; Outback Steakhouse; Peoplesoft, Inc.; Radio One; Restoration Hardware, Inc.; Rock Bottom Restaurants; Staples; Sun Microsystems; Wellfleet Communications; and Wire Networks, Inc. (SBA.gov 2008). Most venture capitalists would be happy to have had these companies in their portfolios. So why are we encouraging and subsidizing the creation of 
marginal businesses instead of focusing government resources on the high potential ones?

The fix to our failing public policies toward entrepreneurship will take political will. There are many more voters that directly benefit from our current policies - they get subsidies and tax benefits from starting companies - than would directly benefit from a focus on high potential companies. The greater benefits from the better policies are diffuse and down the road because they come from having more high growth, job creating companies. So policy makers need to make a choice: do they want to pursue good policies or good politics?

\section{References}

Acs, Z. J., \& Armington, C. (2004). Employment growth and entrepreneurial activity in cities. Regional Studies, 38(8), 911-927.

Armington, C., \& Acs, Z. J. (2003). Job creation and persistence in services and manufacturing. Discussion Papers on Entrepreneurship, Growth, and Public Policy, Max Planck Institute, Number 1604.

Baumgartner, H., \& Caliendo, M. (2007). Turning unemployment into self-employment: Effectiveness and efficiency of two start-up programs. SSRN Working Paper, Number 976874

Bernstein, D. (2002). Fringe benefits and small businesses: Evidence from the Federal Reserve Board small business survey. Applied Economics, 34(16), 2063-2067.

Blanchflower, D. G. (2000). Self-employment in OECD countries. Labour Economics, 7(5), 471-505.

Blau, D. (1987). A time series analysis of self-employment in the United States. Journal of Political Economy, 95(3), 445-465.

Bogenhold, D., \& Staber, U. (1991). The decline and rise of self-employment. Work, Employment and Society, 5(2), 223-239.

Brown, Gordon. (1998). Steering a course for stability. Speech to the board of governors of the International Monetary Fund. Downloaded from http://imf.org/external/am/(1998)/ speeches/PR54GBE.pdf. Accessed on 27 Feb 2009.

Bureau of Labor Statistics. (2008). Overview of Bureau of labor statistics data. Downloaded from http://data.bls.gov/ cgi-bin/surveymost?bls. Accessed on 27 Feb 2009.

Bush, G. W. (2006). Speech to the small business week conference. Downloaded from http://www.whitehouse.gov/ news/releases/(2006)/04/(2006)0413-2.html.

Carree, M., Van Stel, A., Thurik, A. R., \& Wennekers, S. (2002). Economic development and business ownership: An analysis using data of 23 OECD countries in the period 1976-1996. Small Business Economics, 19(3), 271-290.

Case, J. (1995). The wonderland economy. Downloaded from http://www.inc.com/magazine/19950515/2686.html.

Davidsson, P., \& Delmar, F. (2000). Some important observations concerning job creation by firm size and age.
Downloaded from http://eprints.qut.edu.au/archive/00002 078/01/renc98.pdf. Accessed on 27 Feb 2009.

Davis, S. J., \& Haltiwanger, J. (1992). Gross job creation, gross job destruction, and employment reallocation. Quarterly Journal of Economics, 107(3), 819-862.

Gompers, P. A., \& Lerner, J. (2001). The Money of Invention: How venture capital creates new wealth. Boston: Harvard Business School Publishing.

Haltiwanger, J., Lane, J., \& Speltzer, J. (1999). Productivity differences across employers: The roles of employer size, age, and human capital. American Economic Review Papers and Proceedings, 89(2), 94-98.

Haynes, G. (2001). Wealth and income: How did small businesses fare from 1989 to 1998 ? Report for the U.S. Small Business Administration, Contract number SBAHQ-00M-0502.

Henrekson, M. (2007). Entrepreneurship and institutions. Comparative Law and Policy Journal, 28(4), 717-742.

Henrekson, M., \& Johansson, D. (2009). Gazelles as job creators: A survey and interpretation of the evidence. Small Business Economics, forthcoming.

Hippel, S. (2004). Self-employment in the United States: An update. Monthly Labor Review, July, 13-23.

Hurst, E., \& Lusardi, A. (2004). Liquidity constraints, household wealth, and entrepreneurship. Journal of Political Economy, 112(2), 319-347.

InvestinFrance.org. (2008). Save money by thinking: The best research tax credit in Europe. Downloaded from http://www.invest-in-france.org/international/en/the-bestresearch-tax-credit-in-europe.html.

Johnson, P. (2004). Differences in regional firm formation rates: A decomposition analysis. Entrepreneurship Theory and Practice, 28(5), 431-445.

Justlanded.com. (2008). Grants and subsidies in France. Downloaded from http://www.justlanded.com/english/France/Tools/ Just-Landed-Guide/Business/Grants-Subsidies-in-France.

Kirchhoff, B. A. (1994). Entrepreneurship and dynamic capitalism. Westport, CT: Praeger.

Knaup, A. (2005). Survival and longevity in the business employment dynamics data. Monthly Labor Review, May, 50-56.

Lazear, E. M. (2005). Entrepreneurship. Journal of Labor Economics, 23(4), 649-680.

National Venture Capital Association (2004). Venture Impact (2004). Downloaded from http://www.nvca.org/pdf/ VentureImpact2004.pdf.

Noorderhaven, N., Thurik, A. R., Wennekers, S., \& Van Stel, A. (2004). The role of dissatisfaction and per capita income in explaining self-employment across 15 European countries. Entrepreneurship Theory and Practice, 28(5), 447-466.

Persson, H. (2004). The survival and growth of new establishments in Sweden, 1987-1995. Small Business Economics, 23(5), 423-440.

Pratt, J. (1999). Homebased business: The hidden economy. Report for the Office of Advocacy, U.S. Small Business Administration, Contract number SBAHQ-97-M0862.

Reynolds, P. D., \& White, S. (1997). The entrepreneurial process: Economic growth, men, women, and minorities. Westport, CT: Greenwood Publishing Company. 
Small Business Administration (2007). SBIC Program Overview. November. Downloaded from www.sba.gov/idc/ groups/public/documents/sba_program_office/inv_sbic_ program_overview.ppt. Accessed on Feb 272009.

Wagner, J. (1994). The post-entry performance of new small firms in German manufacturing industries. Journal of Industrial Economics, 42(2), 141-154.
Wagner, J. (1997). Firm size and job quality: A survey of the evidence from Germany. Small Business Economics, 9(5), 411-425.

Wellington, A. (2001). Health insurance coverage and entrepreneurship. Contemporary Economic Policy, 19(4), 465478. 